\title{
Individual and Global Optimization of Switched Flux Permanent Magnet Motors
}

\author{
Z.Q. Zhu *, X. Liu **
}

\begin{abstract}
With the aid of genetic algorithm (GA), global optimization with multiple geometry parameters is feasible in the design of switched flux permanent magnet (SFPM) machines. To investigate the advantages of global optimization over individual optimization, which has been used extensively for the design of SFPM machines, a comparison between the two approaches is carried out for the case of fixed copper loss and volume. In the case of individual parameter optimization, the sequence in which the individual parameters are optimized is very important. In the global optimization a better design can always be achieved although the corresponding torque density is found to be only slightly better than that of individually optimized with correct design sequence. By using the obtained global optimization results, the performance in machines having two types of stator and rotor pole combinations, i.e. $12 / 10$ and $12 / 14$, are compared, and it is shown that higher torque is exhibited in the 12/14 SFPM machine. Finally, this paper also demonstrates that global optimization, with the restriction of equal pole width, magnet thickness and slot opening, can maximize the torque density without significantly sacrificing other performance, such as cogging torque and overload capability.
\end{abstract}

Keywords: Average torque, Flux switching, Optimization, Permanent magnet, Switched flux

\section{Introduction}

Switched flux permanent magnet (SFPM) machines are re-emerging as an attractive machine topology with simple but robust rotor structure. Many attempts have been made to use this kind of permanent magnet machine for various applications, ranging from aerospace and automotive to wind power generation. However, the detailed requirements for each application are slightly different, and this leads to the necessity of optimization.

According to the available literature, in order to maximize the torque production at the same current density, the ratio of back-iron thickness to stator pole width is suggested to be $0.7 \sim 0.8$, and the split ratio of inner diameter to outer diameter is suggested to be $0.55 \sim 0.6$ [1]. The optimal ratio of rotor pole width to rotor pole pitch is almost constant, i.e. 1/3, [2]. Harmonics resulting from back-emf can also be minimized by changing the stator pole arc [3]. Based on the investigation of different stator and rotor pole number combinations, the 12/14 SFPM machine

\footnotetext{
* Department of Electronic and Electrical Engineering, University of Sheffield, Sheffield S1 3JD, U.K. (z.q.zhu@sheffield.ac.uk)

** Department of Electronic and Electrical Engineering, University of Sheffield, Sheffield S1 3JD, U.K. (elp09x11@sheffield.ac.uk) Received 08 July 2011 ; Accepted 11 November 2011
}

is considered to have better torque capability than the $12 / 10$ SFPM machine [4], [5]. In the C-core SFPM machine, it has been shown that, as the rotor pole number increases, the optimized ratio of slot opening width to magnet thickness increases [6]. However, the foregoing investigations were mainly carried out with individual-parameter optimization or with different restrictions.

In order to optimize the geometry of a SFPM machine, the influence of the split ratio, stator pole width, magnet thickness, stator back-iron thickness, rotor pole width, and rotor back-iron thickness have been studied in [1] by finite element analysis (FEA). Due to the fact that FEA consumes a lot of time, a lumped circuit model [2] and analytical expression for determining the winding configuration [3] were developed to estimate the optimized design. With the aid of such approaches, final optimized results can be quickly obtained by FEA in a narrowed scope [7]. However, in the aforementioned approaches, the coupling effect between geometry parameters is seldom considered.

Therefore, a global optimization approach combining the genetic algorithm (GA) with FEA, carried out with Ansoft/Maxwell software, is used in this paper to find the real global solution for $12 / 10$ and 12/14 SFPM machines with different objective functions. During the optimization, the copper loss and volume are kept constant. To validate the effectiveness of such an approach, the individual 
optimization solution followed by appropriate sequence is compared to the global optimization solution. With the obtained globally optimized results, the performance of $12 / 10$ and 12/14 SFPM machines are compared in terms of torque density, cogging torque, magnet consumption, flux-linkage, and back-emf. The results show that global optimization, with the restriction that pole width, magnet thickness and slot opening all be the same, can maximize the torque density without significantly sacrificing other performance, such as cogging torque and overload capability.

\section{Individual Optimization of SFPM machines}

Fig. 1 shows the cross-sections of 12/10 and 12/14 SFPM machines, which are to be optimized in this paper. The initial design parameters for these two SFPM machines, which have been used in [1], [2], are listed in Table 1.

To implement individual optimization, the sequence in which design parameters are optimized should follow the level of the parameters' sensitivity. In other words, the most sensitive parameter should be optimized first. The definitions of the design parameters are as follows: $\lambda_{\mathrm{s}}$ is the split ratio, $s_{\mathrm{p}}$ is the stator pole width ratio, $r_{\mathrm{p}}$ is the rotor pole width ratio, $r_{y}$ is the rotor slot depth ratio, $M_{\mathrm{d}}$ is the magnet thickness ratio, $H_{\mathrm{ys}}$ is the back-iron thickness ratio.

$$
\begin{gathered}
\lambda_{s}=D_{r} / D_{s} \\
s_{p}=b_{p s} / \tau_{s} \\
r_{p}=b_{p r} / \tau_{r} \\
r_{y}=h_{p r} /\left(h_{p r}+h_{y r}\right) \\
M_{d}=b_{m} / \tau_{s} \\
H_{y s}=h_{y s} /\left(h_{y s}+h_{p s}\right)
\end{gathered}
$$

where $b_{\mathrm{ps}}, \tau_{\mathrm{s}}, b_{\mathrm{pr}}, \tau_{\mathrm{r}}, h_{\mathrm{pr}}, h_{\mathrm{yr}}, b_{\mathrm{m}}, h_{\mathrm{ys}}$ and $h_{\mathrm{ps}}$ are illustrated in Fig.2. The calculation of the copper loss, $P_{c u}$, is shown in (7), where $k_{\mathrm{p}}, \rho, l, J$, and $S$ denote the packing factor, resistivity, motor active length, current density, and slot area, respectively, and $b_{\text {slot }}$ is shown in Fig.2.

$$
P_{c u}=\frac{3 \pi}{k_{p}} \rho J^{2} \cdot S \cdot\left(l+\tau_{s}-\frac{b_{s l o t}}{2}\right)
$$

With a packing factor of 0.5 , i.e. $k_{\mathrm{p}}=0.5$, a copper loss of $12.9 \mathrm{~W}\left(80^{\circ} \mathrm{C}\right)$ is assumed during the individual optimization. Under such conditions, the parameters are optimized according to the following sequence: (1) split ratio; (2) rotor pole width ratio; (3) stator pole width ratio; (4) magnet width ratio; (5) back-iron thickness; (6) rotor slot depth ratio. Figs.3-6 show the calculated average torque versus the various defined design parameters in both 12/10 and 12/14 SFPM machines. It should be mentioned that little influence of rotor slot depth ratio on the average torque is observed. Thus, the optimized rotor slot depth ratio in both $12 / 10$ and $12 / 14$ is set to 0.41 .

Another phenomenon that is seen during the individual optimization is that the maximum average torque may not increase during the optimization. This is because of the coupling effect among the parameters. For an easy comparison, Table 2 lists the initial design and optimized results for both $12 / 10$ and $12 / 14$ SFPM machines. Compared with the initial values, it is seen that wider stator poles and a thinner stator back-iron are preferred in order to produce higher torque for the given copper loss. After the optimization, $15 \%$ higher torque can be seen in the $12 / 14$ SFPM machine as compared to the 12/10 SFPM.

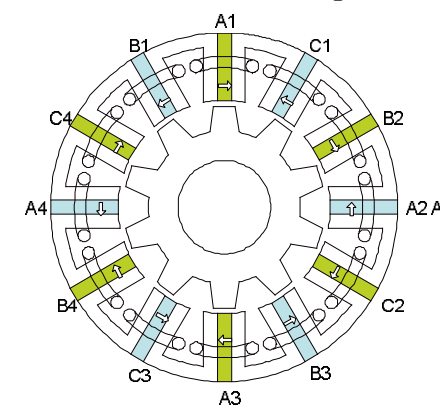

(a)

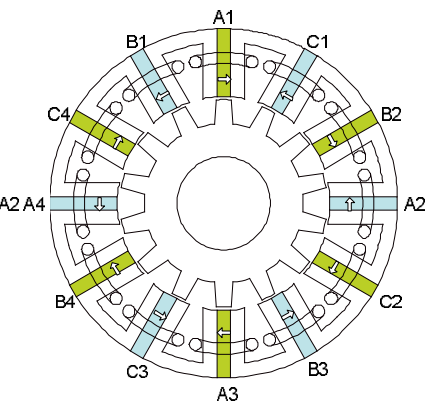

(b)
Fig. 1. Cross section of SFPM machines (a) 12/10 SFPM; and (b) 12/14 SFPM

Table 1. Main Parameters of Prototype SFPM Motors

\begin{tabular}{|l|c|c|}
\hline Number of phases & 3 & 3 \\
\hline Stator pole number, $N_{\mathrm{s}}$ & 12 & 12 \\
\hline Rotor pole number, $N_{\mathrm{r}}$ & 10 & 14 \\
\hline Outer diameter of stator, $D_{\mathrm{s}}$ & $90 \mathrm{~mm}$ & $90 \mathrm{~mm}$ \\
\hline Inner diameter of stator, $D_{\mathrm{r}}$ & $55 \mathrm{~mm}$ & $55 \mathrm{~mm}$ \\
\hline Airgap, $g$ & $0.5 \mathrm{~mm}$ & $0.5 \mathrm{~mm}$ \\
\hline Active axial length, $l$ & $25 \mathrm{~mm}$ & $25 \mathrm{~mm}$ \\
\hline Rotor pole width top/bottom & $5.65 / 7.68 \mathrm{~mm}$ & $3.88 / 4.60 \mathrm{~mm}$ \\
\hline Stator pole width & $3.6 \mathrm{~mm}$ & $3.6 \mathrm{~mm}$ \\
\hline Magnet thickness & $3.6 \mathrm{~mm}$ & $3.6 \mathrm{~mm}$ \\
\hline Back-iron thickness & $3.6 \mathrm{~mm}$ & $3.6 \mathrm{~mm}$ \\
\hline
\end{tabular}

Table 2. Comparison between Initial and Individual Optimized Values

\begin{tabular}{|l|c|c|c|c|}
\hline & \multicolumn{2}{|c|}{$\mathbf{1 2 / 1 0}$ SFPM } & \multicolumn{2}{c|}{ 12/14 SFPM } \\
\hline Variables & $\begin{array}{c}\text { Initial } \\
\text { value }\end{array}$ & $\begin{array}{c}\text { Individual } \\
\text { optimized }\end{array}$ & $\begin{array}{c}\text { Initial } \\
\text { value }\end{array}$ & $\begin{array}{c}\text { Individual } \\
\text { optimized }\end{array}$ \\
\hline$\lambda_{\mathrm{s}}$ & 0.60 & 0.60 & 0.60 & 0.64 \\
\hline$r_{\mathrm{p}}$ & 0.33 & 0.33 & 0.33 & 0.33 \\
\hline$s_{\mathrm{p}}$ & 0.25 & 0.29 & 0.25 & 0.27 \\
\hline$M_{\mathrm{d}}$ & 0.25 & 0.27 & 0.25 & 0.20 \\
\hline$H_{\mathrm{ys}}$ & 0.21 & 0.14 & 0.21 & 0.13 \\
\hline$r_{y}$ & 0.41 & 0.41 & 0.41 & 0.41 \\
\hline
\end{tabular}




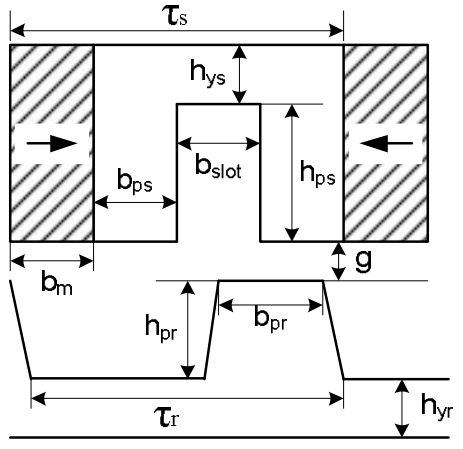

Fig. 2. One module of SFPM machine.

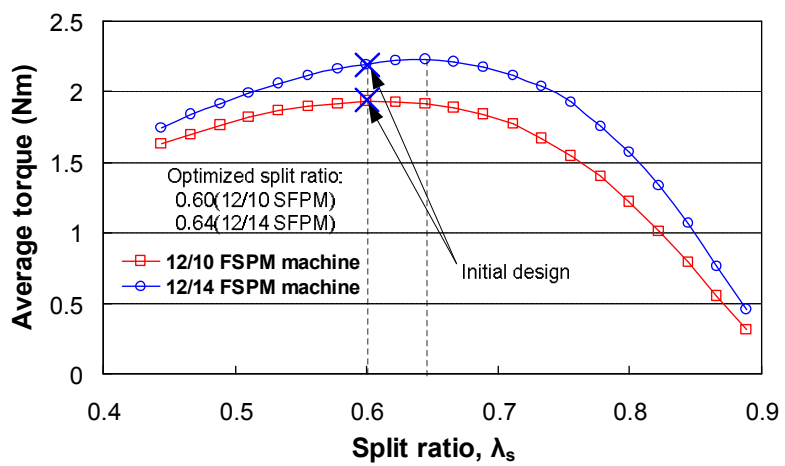

Fig. 3. Average torque versus split ratio in $12 / 10$ and $12 / 14$ SFPM machines.

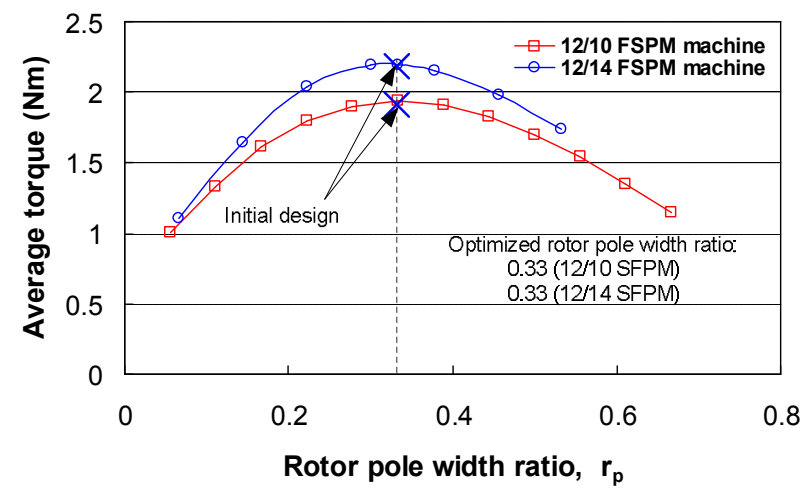

Fig.4. Average torque versus rotor pole width ratio in $12 / 10$ and 12/14 SFPM machines.

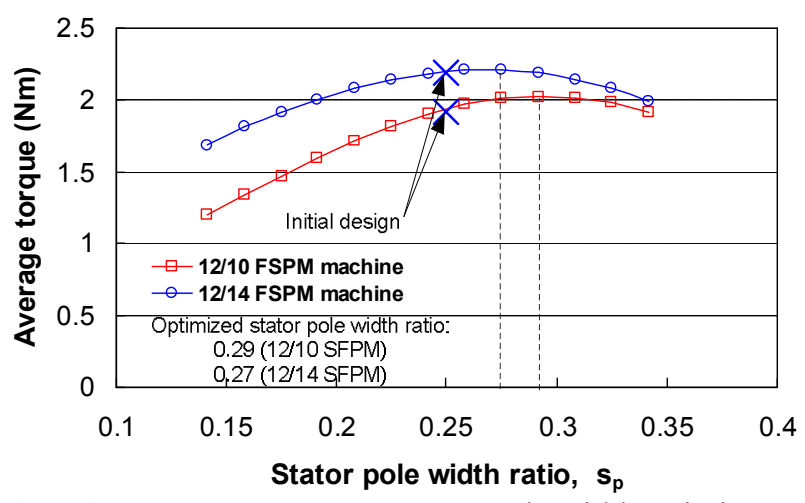

Fig.5. Average torque versus stator pole width ratio in 12/10 and 12/14 SFPM machines.

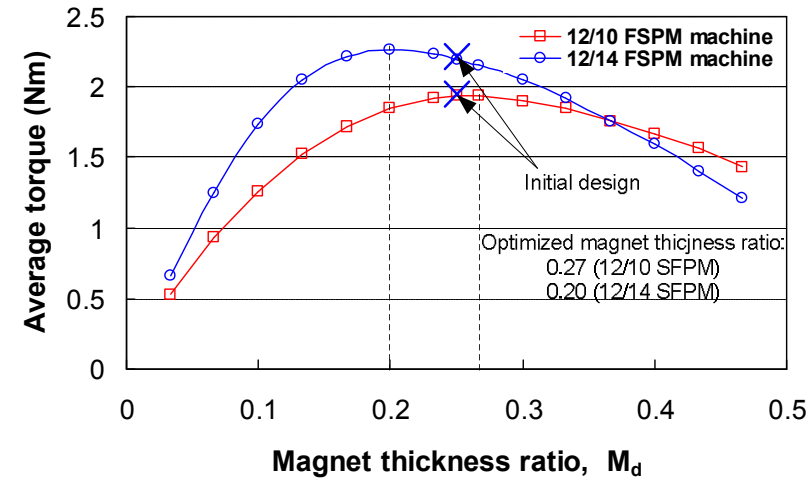

Fig.6. Average torque versus magnet thickness ratio in 12/10 and 12/14 SFPM machines.

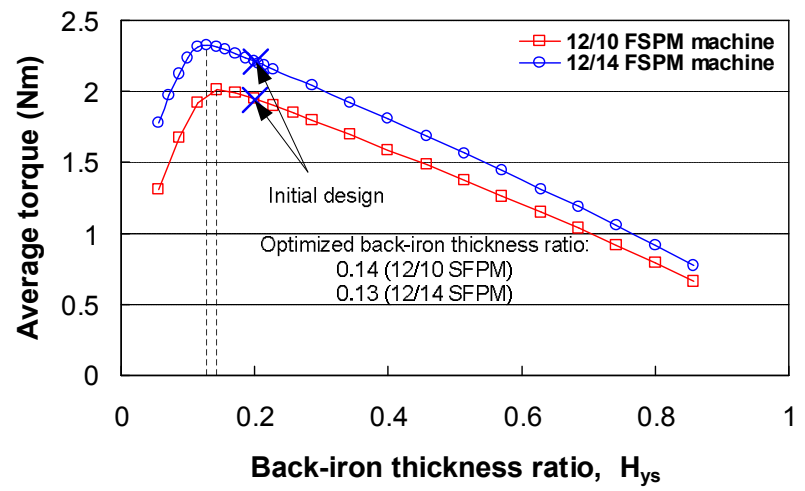

Fig.7. Average torque versus back-iron thickness ratio in 12/10 and 12/14 SFPM machines.

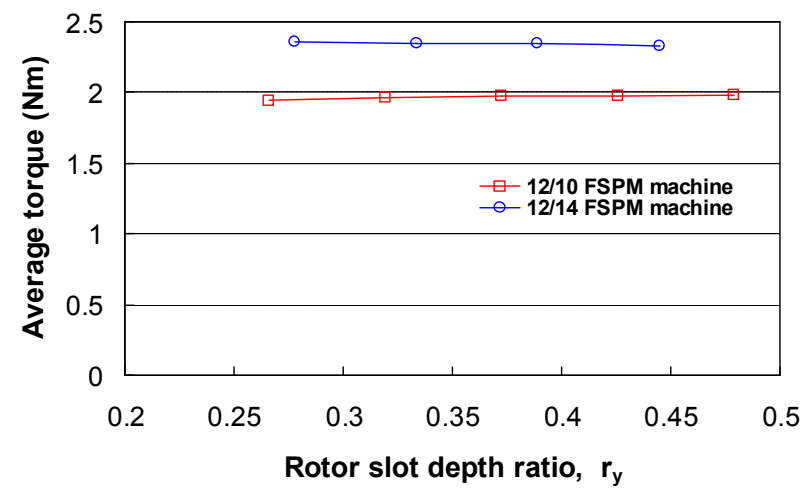

Fig.8. Average torque versus rotor slot depth ratio in 12/ 10 and 12/14 SFPM machines.

\section{Global Optimization of 12/10 SFPM Machine for Maximizing Torque Density}

As one of the most effective numerical optimization methods, GA has been widely used for seeking optimized solutions in applications of motor design. In literature, the maximum torque density and minimum cogging torque are often used as the optimization objectives [8], [9]. They are used in this paper as well. The global optimizations of SFPM machines are carried out with and without the 
restriction of equal stator pole width, magnet thickness and slot opening. It is expected that with fewer variables the optimization solution may be found more quickly.

\subsection{With the restriction of $b_{m}=b_{p s}=b_{\text {slot }}$}

According to the study in [2], the stator pole width, magnet thickness and slot opening are suggested to be equal to each other to produce the maximum average torque. Therefore, the GA is implemented first with such a restriction, and the settings of the GA are as follows: the population size, mating pool size, individual crossover probability and mutation probability are 20, 20, 0.5 and 1 , respectively. The objective function is defined as:

$$
\text { Cost }=-\sum_{i=1}^{n} w_{i} T_{i}
$$

where $w_{\mathrm{i}}$ and $T_{\mathrm{i}}$ denote the weight and torque at specific rotor positions. To optimize the average torque, all the weights are set to be $1 / \mathrm{n}$ and hence their contributions to the average torque at each specific rotor position are all equal. By neglecting the reluctance torque, the $\mathrm{d}$-axis current is set to zero and the copper loss is set to $12.9 \mathrm{~W}$ during the optimization. Table 3 lists the global optimized parameters together with the individual optimized parameters. The up- and down- limitation of parameters are restricted to obtain the reasonable design, shown as constraints in Table 3. No significant difference in terms of average torque is observed between individual and global optimizations, as seen in Table 5.

Table 3. Global Optimization Variables with Restriction of

\begin{tabular}{|c|c|c|c|c|}
\hline $\begin{array}{l}\text { Optimization } \\
\text { parameters }\end{array}$ & $\begin{array}{l}\text { Initial } \\
\text { value }\end{array}$ & $\begin{array}{l}\text { Individual } \\
\text { optimized }\end{array}$ & $\begin{array}{c}\text { constrai } \\
\text { nts }\end{array}$ & $\begin{array}{c}\text { Global } \\
\text { optimized }\end{array}$ \\
\hline Split ratio & 0.60 & 0.60 & $\begin{array}{c}0.56 \\
0.67]\end{array}$ & 0.61 \\
\hline $\begin{array}{l}\text { Rotor pole } \\
\text { width ratio }\end{array}$ & 0.33 & 0.33 & $\begin{array}{l}{[0.22,} \\
0.44]\end{array}$ & 0.34 \\
\hline $\begin{array}{l}\text { Stator pole } \\
\text { width ratio }\end{array}$ & 0.25 & 0.29 & 0.25 & 0.25 \\
\hline $\begin{array}{l}\text { Magnet } \\
\text { thickness ratio }\end{array}$ & 0.25 & 0.27 & 0.25 & 0.25 \\
\hline $\begin{array}{l}\text { Back-iron } \\
\text { thickness ratio }\end{array}$ & 0.21 & 0.14 & $\begin{array}{l}{[0.03,} \\
0.28]\end{array}$ & 0.16 \\
\hline $\begin{array}{l}\text { Rotor slot } \\
\text { depth ratio }\end{array}$ & 0.41 & 0.41 & $\begin{array}{l}{[0.29} \\
0.53]\end{array}$ & 0.48 \\
\hline
\end{tabular}

Note: Constraints are the range within which each parameter may vary.

\subsection{Without any restriction}

If the restriction is removed, even higher average torque should be expected. After the implementation of global optimization, Table 4 shows the solution under the condition of fixed copper loss. In the case of global optimization without restriction, more variables are changing during the procedure. Therefore, the possibility to obtain the global optimal torque in a short time period is reduced, as shown in Fig.9. Compared with the individual optimization, the time required for global optimization is often much longer since more iterations are required. However, due to the random characteristics of GA, the time consumption under global optimization is always difficult to determine. Moreover, it can be seen in Fig.9 that during the global optimization the Cost is likely to convergent to several values, which are named as the local optimizations and global optimization. One of the advantages of GA is its capability to converge to the global optimal point, Fig.9

By comparing the optimized results, very little improvement is achieved in terms of torque density if no restriction is applied, as compared to the case in which the restriction from applied. Therefore, to optimize the torque density, both the individual and global optimizations with restriction of $b_{\mathrm{m}}=b_{\mathrm{ps}}=b_{\text {slot }}$ can achieve good solutions in the design of SFPM machines. Regarding other critical issues, such as magnet consumption and slot area, global optimization with the restriction is also acceptable compared with other approaches. For a direct comparison of all designs, the laminations are illustrated in Fig. 10.

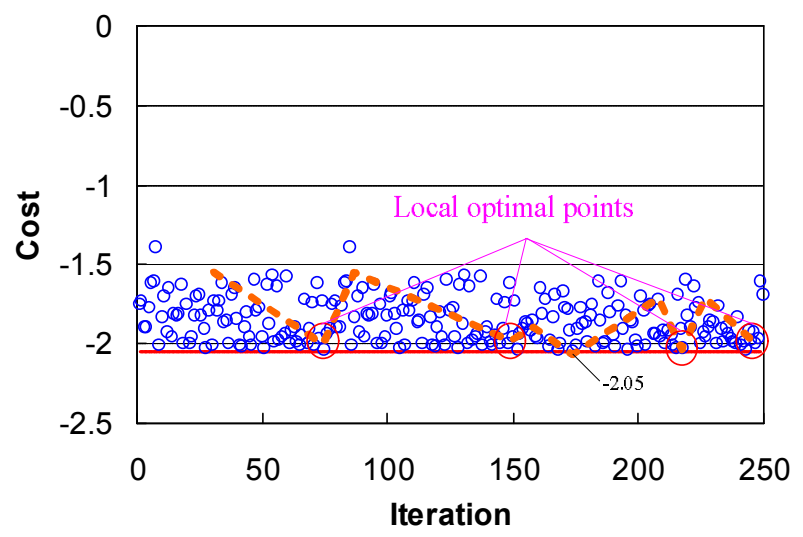

(a) With restriction of $b_{m}=b_{p s}=b_{\text {slot }}$

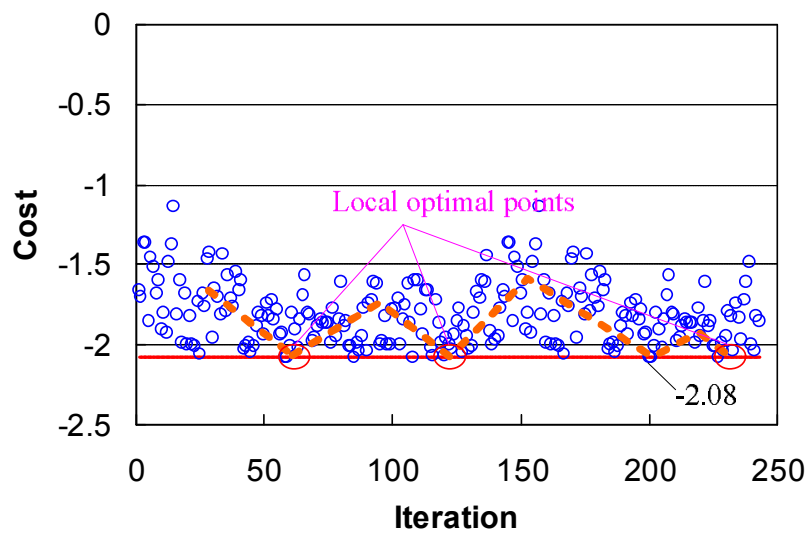

(b) Without restriction

Fig.9. Optimization procedure by GA for 12/10 SFPM machine. 


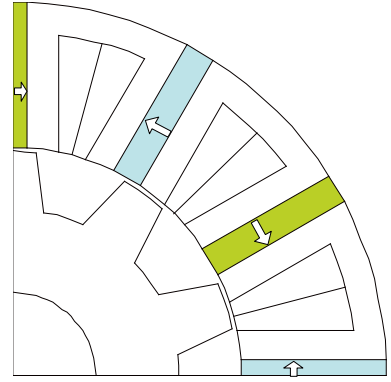

(a) Initial design

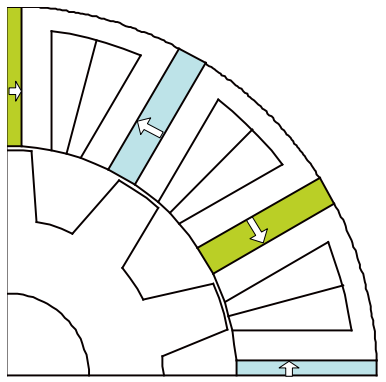

(c) Global optimization with $b_{\mathrm{m}}=b_{\mathrm{ps}}=b_{\text {slot }}$

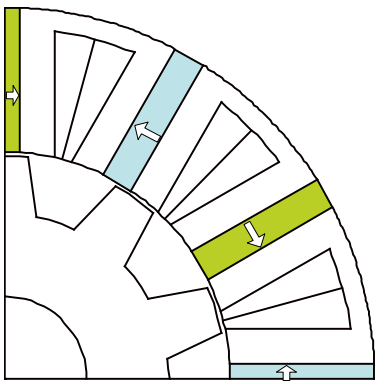

(b) Individual optimization

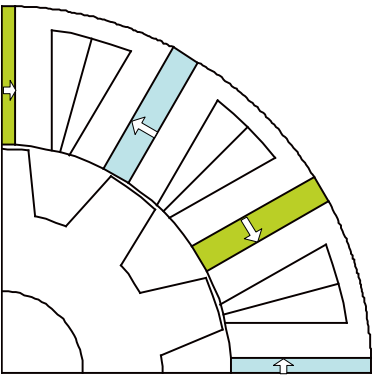

(d) Global optimization without restriction
Fig.10. Illustration of laminations of 12/10 SFPM machines

Table 4. Global Optimization Variables without Restriction Of $b_{m}=b_{p s}=b_{\text {slot }}$ and Constraints in 12/10 SFPM Motor

\begin{tabular}{|l|c|c|c|c|}
\hline $\begin{array}{l}\text { Optimization } \\
\text { parameters }\end{array}$ & $\begin{array}{c}\text { Initial } \\
\text { value }\end{array}$ & $\begin{array}{c}\text { Individual } \\
\text { optimized }\end{array}$ & $\begin{array}{c}\text { Con- } \\
\text { straints }\end{array}$ & $\begin{array}{c}\text { Global } \\
\text { optimized }\end{array}$ \\
\hline Split ratio & 0.60 & 0.60 & $\begin{array}{c}{[0.56,} \\
0.67]\end{array}$ & 0.61 \\
\hline $\begin{array}{l}\text { Rotor pole } \\
\text { width ratio }\end{array}$ & 0.33 & 0.33 & $\begin{array}{c}{[0.22,} \\
0.44]\end{array}$ & 0.39 \\
\hline $\begin{array}{l}\text { Stator pole } \\
\text { width ratio }\end{array}$ & 0.25 & 0.29 & $\begin{array}{c}{[0.17,} \\
0.33]\end{array}$ & 0.29 \\
\hline $\begin{array}{l}\text { Magnet } \\
\text { thickness ratio }\end{array}$ & 0.25 & 0.27 & $\begin{array}{c}{[0.13,} \\
0.33]\end{array}$ & 0.24 \\
\hline $\begin{array}{l}\text { Back-iron } \\
\text { thickness ratio }\end{array}$ & 0.21 & 0.14 & $\begin{array}{c}{[0.03,} \\
0.28]\end{array}$ & 0.15 \\
\hline $\begin{array}{l}\text { Rotor slot } \\
\text { depth ratio }\end{array}$ & 0.41 & 0.41 & $\begin{array}{c}{[0.29,} \\
0.53]\end{array}$ & 0.45 \\
\hline
\end{tabular}

Note: Constraints are the range within which each parameter may vary.

Table 5. Motor Design Comparisons between Initial, Individual, and Global Optimizations in $12 / 10$ SFPM Machine

\begin{tabular}{|l|c|c|c|c|}
\hline \multirow{2}{*}{$\begin{array}{l}\text { Optimization } \\
\text { parameters }\end{array}$} & \multirow{2}{*}{$\begin{array}{c}\text { Initial } \\
\text { value }\end{array}$} & $\begin{array}{c}\text { Indivi- } \\
\text {-dual } \\
\text { Optimi- } \\
\text {-zed }\end{array}$ & \multicolumn{2}{|c|}{$\begin{array}{c}\text { Global } \\
\text { optimized }\end{array}$} \\
\cline { 4 - 5 } & $\begin{array}{c}\mathrm{b}_{\mathrm{m}}=\mathrm{b}_{\mathrm{ps}} \\
=\mathrm{b}_{\mathrm{slot}}\end{array}$ & $\begin{array}{c}\mathrm{b}_{\mathrm{m}} \neq \mathrm{b}_{\mathrm{ps}} \\
\neq \mathrm{b}_{\text {slot }}\end{array}$ \\
\hline Mass of magnet $(\mathrm{g})$ & 143.4 & 157.4 & 142.2 & 139.4 \\
\hline Slot area $\left(\mathrm{mm}^{2}\right)$ & 100.2 & 91.4 & 105.9 & 89.2 \\
\hline Average torque* $(\mathrm{Nm})$ & 1.93 & 2.05 & 2.05 & 2.08 \\
\hline
\end{tabular}

*Average torque at copper loss of $12.9 \mathrm{~W}$ at $80^{\circ} \mathrm{C}$.

\section{Global Optimization of 12/14 SFPM Machine for Maximizing Torque Density}

For comparing the performance between optimized 12/10 and 12/14 SFPM machines, the global optimization with/without the restriction of $b_{m}=b_{p s}=b_{\text {slot }}$ are also carried out for the 12/14 SFPM machine. In this way, the influence due to other geometry parameters can be excluded. Hence, only the stator and rotor pole combination may affect the average torque. However, due to the space limitation, only the final optimized results are listed in Table 6 and Table 7.

In terms of magnet consumption, advantages of the 12/14 SFPM machine are observed compared to the 12/10 SFPM machine, as shown in Table 8 . Moreover, higher torque can also be achieved in the 12/14 SFPM machine at the copper loss of $12.9 \mathrm{~W}$.

Table 6. Global Optimization Variables with Restriction of $\mathrm{b}_{\mathrm{m}}=\mathrm{b}_{\mathrm{ps}}=\mathrm{b}_{\text {slot }}$ and Constraints in 12/14 SFPM Motor

\begin{tabular}{|l|c|c|c|c|}
\hline $\begin{array}{l}\text { Optimization } \\
\text { parameters }\end{array}$ & $\begin{array}{c}\text { Initial } \\
\text { value }\end{array}$ & $\begin{array}{c}\text { Individual } \\
\text { optimized }\end{array}$ & $\begin{array}{c}\text { Con- } \\
\text { straints }\end{array}$ & $\begin{array}{c}\text { Global } \\
\text { optimized }\end{array}$ \\
\hline Split ratio & 0.60 & 0.64 & $\begin{array}{c}0.56, \\
0.67]\end{array}$ & 0.64 \\
\hline $\begin{array}{l}\text { Rotor pole } \\
\text { width ratio }\end{array}$ & 0.33 & 0.33 & $\begin{array}{c}0.22, \\
0.44]\end{array}$ & 0.33 \\
\hline $\begin{array}{l}\text { Stator pole } \\
\text { width ratio }\end{array}$ & 0.25 & 0.27 & 0.25 & 0.25 \\
\hline $\begin{array}{l}\text { Magnet } \\
\text { thickness ratio }\end{array}$ & 0.25 & 0.20 & 0.25 & 0.25 \\
\hline $\begin{array}{l}\text { Back-iron } \\
\text { thickness ratio }\end{array}$ & 0.21 & 0.13 & $\begin{array}{c}0.03, \\
0.28]\end{array}$ & 0.14 \\
\hline $\begin{array}{l}\text { Rotor slot } \\
\text { depth ratio }\end{array}$ & 0.41 & 0.41 & $\begin{array}{c}0.29, \\
0.53]\end{array}$ & 0.41 \\
\hline
\end{tabular}

Note: Constraints are the range within which each parameter may vary.

Table 7. Global Optimization Variables without Restriction of $b_{\mathrm{m}}=b_{\mathrm{ps}}=b_{\text {slot }}$ and Constraints in 12/14 SFPM Motor

\begin{tabular}{|l|c|c|c|c|}
\hline $\begin{array}{l}\text { Optimization } \\
\text { parameters }\end{array}$ & $\begin{array}{c}\text { Initial } \\
\text { value }\end{array}$ & $\begin{array}{c}\text { Individual } \\
\text { optimized }\end{array}$ & $\begin{array}{c}\text { Con- } \\
\text { straints }\end{array}$ & $\begin{array}{c}\text { Global } \\
\text { optimized }\end{array}$ \\
\hline Split ratio & 0.60 & 0.64 & $\begin{array}{c}{[0.56,} \\
0.67]\end{array}$ & 0.63 \\
\hline $\begin{array}{l}\text { Rotor pole } \\
\text { width ratio }\end{array}$ & 0.33 & 0.33 & $\begin{array}{c}{[0.07,} \\
0.53]\end{array}$ & 0.38 \\
\hline $\begin{array}{l}\text { Stator pole } \\
\text { width ratio }\end{array}$ & 0.25 & 0.27 & $\begin{array}{c}{[0.17,} \\
0.33]\end{array}$ & 0.26 \\
\hline $\begin{array}{l}\text { Magnet } \\
\text { thickness ratio }\end{array}$ & 0.25 & 0.20 & $\begin{array}{c}{[0.13,} \\
0.33]\end{array}$ & 0.20 \\
\hline $\begin{array}{l}\text { Back-iron } \\
\text { thickness ratio }\end{array}$ & 0.21 & 0.13 & $\begin{array}{c}{[0.03,} \\
0.28]\end{array}$ & 0.14 \\
\hline $\begin{array}{l}\text { Rotor slot } \\
\text { depth ratio }\end{array}$ & 0.41 & 0.41 & $\begin{array}{c}{[0.29,} \\
0.53]\end{array}$ & 0.43 \\
\hline
\end{tabular}

Note: Constraints are the range within which each parameter may vary. 
Table 8. Design Comparisons between Initial, Individual, and Global Optimizations in 12/14 SFPM Machine

\begin{tabular}{|l|c|c|c|c|}
\hline \multirow{2}{*}{$\begin{array}{l}\text { Optimization } \\
\text { parameters }\end{array}$} & \multirow{2}{*}{$\begin{array}{c}\text { Initial } \\
\text { value }\end{array}$} & $\begin{array}{c}\text { Indivi- } \\
\text {-dual } \\
\text { Optimi- } \\
\text {-zed }\end{array}$ & $\begin{array}{c}\text { Global } \\
\text { optimized }\end{array}$ \\
\cline { 4 - 5 } & & $\begin{array}{c}\mathrm{b}_{\mathrm{m}}=\mathrm{b}_{\mathrm{ps}} \\
=\mathrm{b}_{\text {slot }}\end{array}$ & $\begin{array}{c}\mathrm{b}_{\mathrm{m}} \neq \mathrm{b}_{\mathrm{ps}} \\
\neq \mathrm{b}_{\text {slot }}\end{array}$ \\
\hline Mass of magnet $(\mathrm{g})$ & 143.4 & 109.6 & 137.1 & 111.0 \\
\hline Slot area $\left(\mathrm{mm}^{2}\right)$ & 100.2 & 99.9 & 97.5 & 101.6 \\
\hline Average torque* $(\mathrm{Nm})$ & 2.17 & 2.36 & 2.33 & 2.38 \\
\hline
\end{tabular}

*Average torque at copper loss of $12.9 \mathrm{~W}$ at $80^{\circ} \mathrm{C}$.

\section{Performance Comparison between $12 / 10$ and $12 / 14$ SFPM Machines}

\subsection{Torque with fixed copper loss}

As mentioned early, the copper loss is kept constant during the optimization, so as to increase the torque density for a given copper loss. To evaluate the torque production capability, a new coefficient is defined as:

$$
k_{c}=J \cdot \sqrt{S}
$$

The copper loss is proportional to the square of this coefficient, i.e.

$$
P_{c u}=\frac{3 \pi}{k_{p}} \rho k_{c}^{2} \cdot\left(l+\tau_{s}-\frac{b_{s l o t}}{2}\right)
$$

Fig.11 shows the average torque versus $k_{\mathrm{c}}$ for both the $12 / 10$ and the $12 / 14$ SFPM machines. Higher torque exists in the $12 / 14$ SFPM machine compared with the $12 / 10$ SFPM machine. However, since the copper loss was fixed at $12.9 \mathrm{~W}\left(k_{\mathrm{c}}=2.8 \times 10^{3}\right)$ during the optimization, the optimal average torque in the global optimization without restriction found for this choice of copper loss may not be achieved at other given values of copper loss, such as overload condition.

To validate the FEA calculations, the initial designs of the $12 / 10$ and $12 / 14$ SFPM machines were selected to be identical to those in [5].

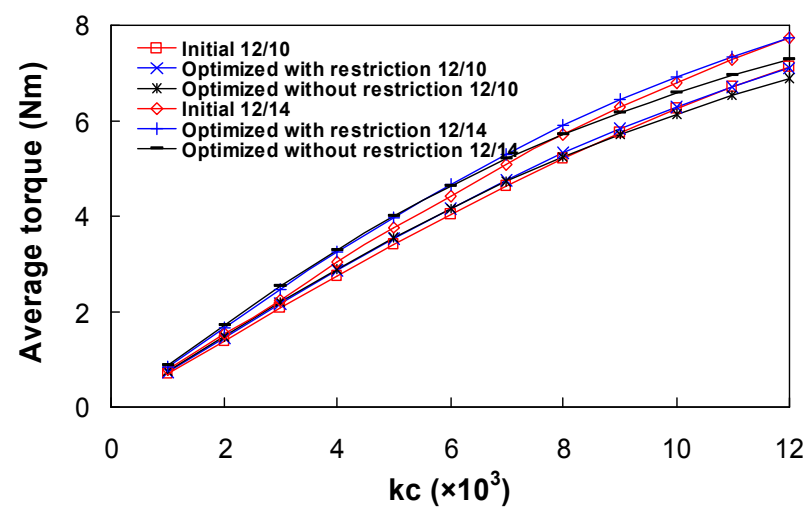

Fig.11. Comparison of torque-current characteristics with $I_{\mathrm{d}}=0$.

\subsection{Cogging torque comparison}

The comparisons of cogging torque, which is a main contributor to the torque ripple, in the initial and global optimizations are shown in Fig.12. Compared with the $12 / 10$ SFPM machine, lower cogging torque is observed in the $12 / 14$ SFPM machine for both the initial and optimized designs. If no restriction is applied in the global optimization, high cogging torque is observed in the $12 / 10$ SFPM machine. On the other hand, the calculation results show that with the restriction of $b_{m}=b_{p s}=b_{\text {slot }}$ in both $12 / 10$ and 12/14 SFPM machines the cogging torque will not be excessive in the globally optimized case.

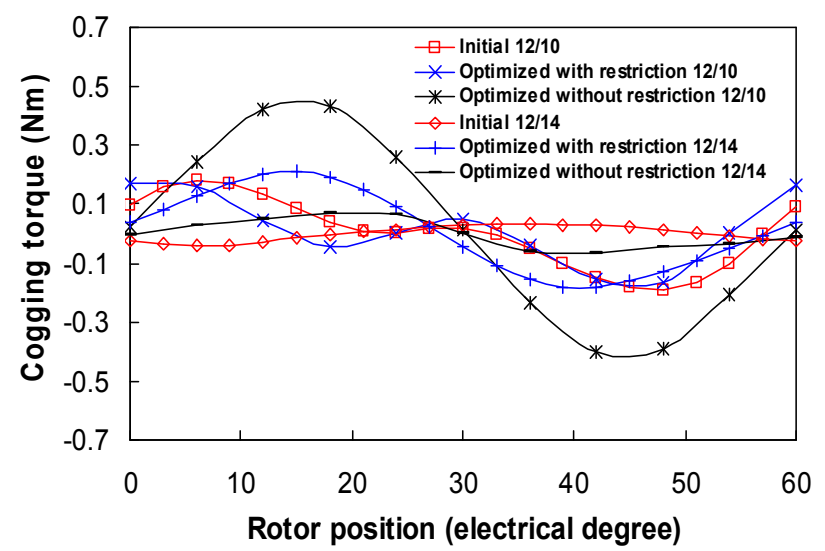

Fig.12. Cogging torque comparison between 12/10 and 12/14 SFPM machines.

\subsection{Flux linkage and back-EMF}

Fig.13 compares the open circuit flux linkages for both $12 / 10$ and 12/14 SFPM machines, together with the harmonic spectra in which it can be seen that the first harmonic, i.e. the fundamental component of flux linkage, is dominant. Similar to the torque characteristic at the fixed copper loss, the fundamental component of flux linkage is increased in both optimized 12/10 and 12/14 SFPM machines. Noting that the electromagnetic torque is proportional to the product of flux linkage and pole pair number, smaller flux linkage in the 12/14 SFPM machine will not lead to lower electromagnetic torque.

Finally, Fig.14 shows the phase back-EMF waveforms and spectra, i.e. $e_{\mathrm{ph}}=e_{1}+e_{2}+e_{3}+e_{4}$, since each phase winding consists of four coils connected in series, as shown in Fig.1. The 12/14 SFPM machine has less harmonics but a larger fundamental component. 


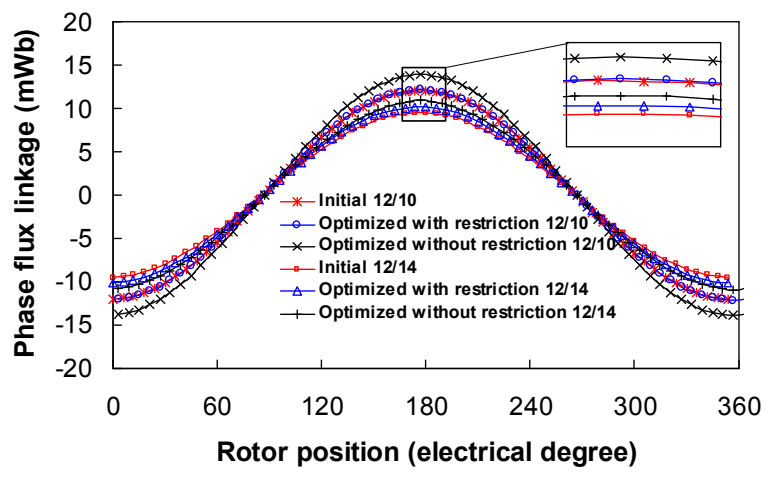

(a) Waveforms of flux-linkage

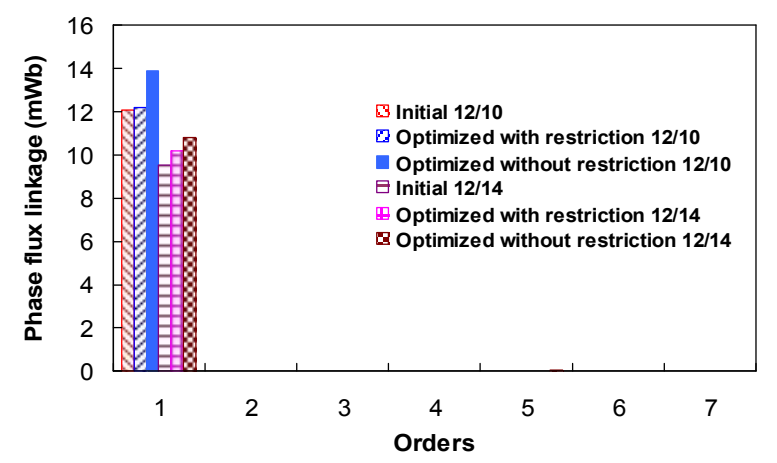

(b) Spectra of flux-linkage

Fig.13. Flux-linkage in both $12 / 10$ and 12/14 SFPM machines with/without optimization.

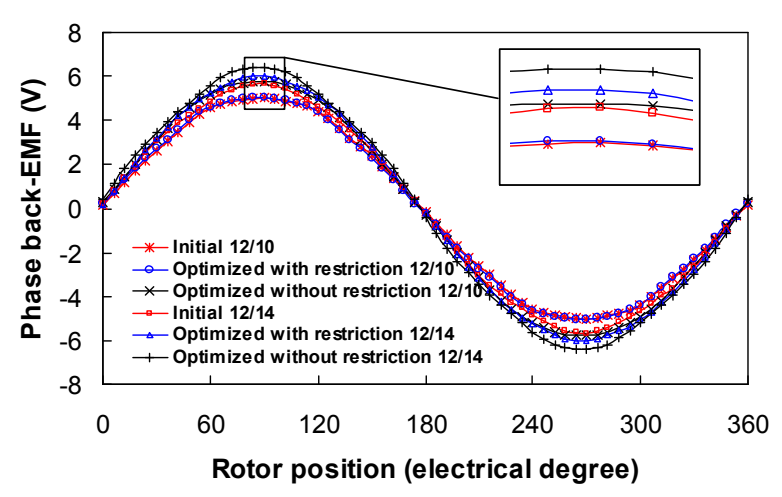

(a) Waveforms

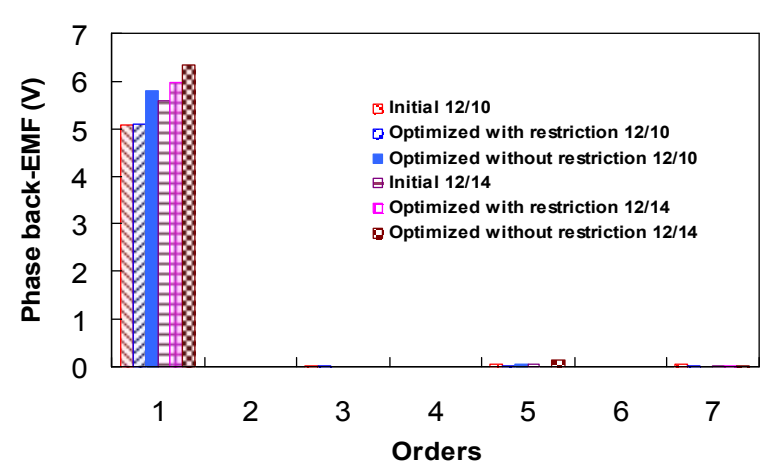

(b) Spectra

Fig.14. Phase back-emf in both $12 / 10$ and $12 / 14$ SFPM machines with/without optimization

\section{Conclusions}

To evaluate the effectiveness of global optimization of SFPM machines by genetic algorithm, both individual and global optimizations of 12/10 and 12/14 SFPM machines were carried out in this paper. Compared with the individual optimization, the global optimization can be employed without considering the optimization sequence, and always achieve better design, but it produces only slightly higher average torque at fixed copper loss than that obtained by the individual optimization with a correct optimization sequence for the parameters. The results show that, with the aid of global optimization, higher torque but less cogging torque in the 12/14 SFPM machine is achieved. Moreover, it was found that, with the restriction of $\mathrm{b}_{\mathrm{m}}=\mathrm{b}_{\mathrm{ps}}=\mathrm{b}_{\text {slot }}$ during the global optimization, the improvement of average torque did not cause high cogging torque.

\section{References}

[1] Z.Q. Zhu, Y. Pang, J.T. Chen, Z.P. Xia, and D. Howe, "Influence of design parameters on output torque of fluxswitching permanent magnet machines," IEEE Conf. Vehicle Power and Propulsion, Sep. 3-5, 2008. Harbin, China.

[2] Z.Q. Zhu, Y. Pang, D. Howe, S. Iwasaki, R. Deodhar, and A. Pride, "Analysis of electromagnetic performance of fluxswitching permanent magnet machines by nonlinear adaptive lumped parameter magnetic circuit model," IEEE Trans. Magnetics, vol.41, no.11, pp.4277-4287, 2005.

[3] W. Hua, M. Cheng, Z.Q. Zhu, and D. Howe, "Analysis and optimization of back EMF waveform of a flux-switching permanent magnet motor," IEEE Trans. Energy Conversion, vol.23, no.3, pp. 727-733, Sep. 2008.

[4] J.T. Chen, and Z.Q. Zhu, "Comparison of all- and alternatepoles-wound flux-switching PM machines having different stator and rotor pole number," IEEE Trans. Industry Applications, vol.46, no.4, pp.1406-1415, Jul./Aug. 2010.

[5] J.T. Chen, and Z.Q. Zhu, "Winding configurations and optimal stator and rotor pole combination of flux-switching PM brushless AC machine," IEEE Trans. Energy Conversion, vol.25, no.2, pp.293-302, Jun. 2010.

[6] J.T. Chen, Z.Q. Zhu, S. Iwasaki, and R. Deodhar, "Influence of slot opening on optimal stator and rotor pole combination and electromagnetic performance of flux-switching PM brushless AC machines," Energy Conversion Congress and Exposition, 2010, 12-16 Sep. Atlanta, USA.

[7] J.T. Chen, Z.Q. Zhu, and D. Howe, "Stator and rotor pole combination for multi-tooth flux-switching permanentmagnet brushless AC machines," IEEE Trans. Magnetics, vol.44, no.12, pp.4659-4667, Dec. 2008.

[8] W. Min, J.T. Chen, Z.Q. Zhu, Y. Zhu, M. Zhang, and G.H. Duan, "Optimization of linear switched flux permanent magnet machine," IEEE Conf. Vehicle Power and Propulsion (VPPC2010), 2010, 1-3 Sep. Lille.

[9] M. Lukaniszyn, M. Jagiela, and R. Wrobel, "Optimization of permanent magnet shape for minimum cogging torque using a genetic algorithm," IEEE Trans. Magnetics, vol.40, no.2, pp.1228-1231, March, 2004. 
[10] J.T. Chen, Z.Q. Zhu, "Influence of the rotor pole number on optimal parameters in flux-switching PM brushless AC machine by the lumped-parameter magnetic circuit model," IEEE Trans.Ind. Appl., vol.46, no.4, pp.1381-1388, Jul./Aug. 2010.

[11] Z.Q. Zhu, J.T. Chen, "Advanced flux-switching permanent magnet brushless machines," IEEE Trans. Magnetics, vol.46, no.6, pp.1447-1453, Jun. 2010.

[12] A. Chen, N. Rotevatn, R. Nilssen, and A. Nysveen, "Characteristic investigations of a new three-phase fluxswitching permanent magnet machine by FEM simulations and experimental verification," International Conf. Electrical Machines and Systems, 2009, 15-18 Nov. 2009, Tokyo, Japan.

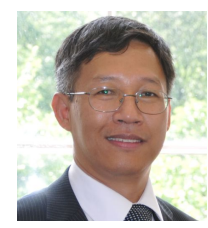

Z. Q. Zhu received the B.Eng. and M.Sc. degrees from Zhejiang University, Hangzhou, China, in 1982 and 1984, respectively, and the Ph.D. degree from the 1991. University of Sheffield, Sheffield, U.K., in

Since 1988, he has been with the University of Sheffield, where he is currently a Professor at the Department of Electronic and Electrical Engineering, and Head of the Electrical Machines and Drives Research Group. His current major research interests include design and control of permanent magnet brushless machines and drives, for applications ranging from automotive to renewable energy.

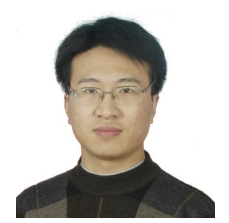

\section{Liu}

$\mathrm{He}$ received the B.Eng. and $\mathrm{PhD}$ degrees from Zhejiang University, Hangzhou, China, in 2005 and 2010, respectively, all in electrical engineering. He is currently a Post-doctorial Researcher at the Department of Electronics and Electrical Engineering, University of Sheffield, Sheffield, U.K. His current research interests include designs and applications of switched reluctance and permanent magnet machines and drives. 